УДК 340.1

DOI https://doi.org/10.32837/yuv.v0i3.2182

I. Криховецький,

кандидат економічних наук, докторант

Університету Короля Данила

\title{
ВПЛИВ СЕЙМОВОЇ ДІЯЛЬНОСТІ НА ЕВОЛЮЦІЮ УКРАЇНСЬКИХ СУСПІЛЬНО-ПОЛІТИЧНИХ ТЕЧІЙ ДРУГОЇ ПОЛОВИНИ ХІХ - ПОЧАТКУ ХХ СТ.
}

Постановка проблеми. Друга половина XIX - початок XX ст. стали часом активізації українського національного руху. Тенденційно як у Наддніпрянщині, що входила до складу імперії Романових, так і на західноукраїнських землях, які були частиною Австрійської імперії, відбувається національно-культурне піднесення, в рамках якого активізується i суспільно-політичне життя, формуються концепції національного державотворення. 3 огляду на ліберальний характер австрійської імперської влади конституційні перетворення і гарантування широких прав і свобод усім народам імперії, у Галичині процеси політизації національного руху відбувалися найшвидше. Активізації суспільно-політичного життя не був перешкодою навіть слабкий соціально-економічний розвиток Галичини, а також те, що керівний провід в національному русі займало духовенство.

Активізація політичного життя в Галичині відбулася під час загальноєвропейської революції «Весни народів» 1848-1849 рр., коли місцеві українці в травні 1848 р. створили власну політичну організацію Головну Руську Раду, політична програма дій якої передбачала поділ Галичини за національною ознакою та надання українській східній частині широких національно-політичних і культурних прав.

Відомий громадський діяч середини XIX ст. В. Подолинський, характери- зуючи події 1848-1849 рр., вказував, що в середові українців чітко виокремилося чотири суспільно-політичні течії: австрофільська, русофільська, полонофільська та українофільська [10]. Назва кожної із цих течій демонструє іï ідеологічну спрямованість. Однак найбільш сталими виявилися русофільська та українофільська течії, які згодом трансформувалися у русофільську та народовську відповідно.

При цьому слід звернути увагу й на те, що поділ, запропонований В. Подолинським був умовним, адже український національний рух 1848-1849 рр. був цілісним, а в його середовищі були популярними згадані течії. Єдиним український національний рух залишався і до початку 1860-х pр., часу створення крайових сеймів. Саме нормотворча діяльність Галицького сейму спричинилася до чіткої структуризації національного руху, виявлення політичних розбіжностей між його представниками.

Загалом для досліджуваного нами періоду - другої половини XIX - початку XX ст. для галичан була властивою наявність трьох політичних течій - русофільської (москвофільської), народовської та радикальної.

Аналіз останніх досліджень і публікацій. Вивчення українського суспільно-політичного руху Галичини другої половини XIX - початку XX ст. здійснюється майже винятково істориками. Натомість серед 
правників домінує підхід, коли практична діяльність і політичні програми русофілів, народовців чи радикалів розглядаються крізь призму аналізу політичного становища Галичини у складі імперії Габсбургів. Загалом впродовж останніх десятиліть світ побачили багато праць, які розкривають процес формування, організаційного і навіть партійного оформлення основних суспільно-політичних течій Галичини другої половини XIX початку XX ст.

Методологічною основою нашого дослідження стали праці О. Аркуші, М. Драгоманова, Л. Ілина, В. Лавринюка, К. Левицького, Ю. Михальського, М. Мудрого, В. Подолинського, О. Салтовського, Т. Слотюка, I. Франка, I. Чорновола та ін.

Постановка завдання. Метою нашого дослідження $€$ визначення впливу сеймової діяльності на еволюцію основних суспільно-політичних течій галицьких українців другої половини XIX - початку XX ст.

Виклад основного матеріалу дослідження. Початок роботи Галицького сейму став новим етапом у розвитку національного руху галицьких українців. Сеймова діяльність чітко продемонструвала відмінності між представниками різних поколінь галицького політикуму. Русофіли та народовці, хоч і змушені були діяти консолідовано на передодні та під час виборів до сейму, в процесі нормотворчої діяльності були абсолютно різними за політичним спрямуванням суспільно-політичними течіями.

Загравання русофілів з ідеями панславізму призвели до того, що Російська імперія звернула на них увагу і надавала їм певну допомогу. Для підтримки русофілів імперія Романових вдавалася і до різного роду зловживань і просування в політичний простір Австрії вигідних їй політиків. Прикладом може стати відомий галицький русофіл $M$. Антоневич, який був племінником Я. Голо- вацького та підтримував стосунки з відомим російським пропагандистом M. Раєвським. Упродовж 1870-х 1880-х рр. М. Антоневич зарекомендував себе активним політичним діячем, постійно обирався до Галицького сейму та був одним із найініціативніших послів. М. Антоневич був одним із найбільших противників угодовської кампанії «нової ери», яка реалізовувалася за ініціативи народовців у 1890-1892 рр. [14, с. 187].

Така ситуація призвела до того, що польський політикум Галичини почав підтримувати народовців як єдину силу, що могла сформувати альтернативу русофілам. Підтримка поляками народовців була закономірною з огляд на бажання перших налагодити політичний компроміс. Формально ідеологом галицького народовства можна вважати ідейного лідера «Руської трійці» $M$. Шашкевича. Оцінюючи його вплив на політичну свідомість галичан другої половини XIX ст., К. Левицький писав, що M. Шашкевич «кинув між нас світло національної свідомості і пробудив почуття одноцілосності всього українського народу» [6, с. 7-9]. Згідно із твердженням K. Левицького, початком формування народовської течії, так само як і русофільської, є 1848 р. Характеризуючи ідеологічний вплив згаданого М. Шашкевича, він писав, що «його заповіт підняли народовці з 1848 року, кладучи перші основи до національної будівлі» [6, с. 7-9]. Відповідно, народовці, так само як і русофіли, декларуючи єдність українського народу, бачили його розвиток виключно під скіпетром імперії Габсбургів. Такий лібералізм до імперської влади сприяв у закономірній підтримці цієї суспільно-політичної течії з боку Відня, хоча явної допомоги, як це мало місце з русофілами та Російською імперією, не було.

Характерно, що на момент свого створення, та ідеологічного оформлення ані русофіли, ані народовці у 1860-1880-х рр. не були готові до 


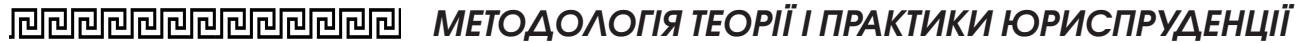

самостійної політичної діяльності. Перші розуміли ініціативи поляків із підтримки народовців як бажання «розсварити русинів», а другі у порозумінні бачили можливість легально i 3 правової точки зору відстояти власні національно-культурні інтереси.

Протистояння з поляками, а також перші сеймові каденції продемонстрували, що тільки єдність русофілів і народовців може гарантувати їм успіх у стінах сейму. Не зовсім вдалі вибори 1867 р. у порівнянні з виборами 1861 р. змусили галицьких українців до пошуків нових форм організаційного оформлення. Ініціатором створення політичного товариства галичан став Ю. Лаврівський, чия угодовська акція 1869-1870 рр. зазнала невдачі. 3 метою недопущення розколу українства він запропонував створити політичний орган «Руську Раду» [5, с. 32]. Українське суспільство вітало створення подібної організації, про що свідчать публікаціі з газети «Слово, яка писала, що «час пасивності закінчився і пора активно діяти» [8, с. 1]. Цікаво, що після усіх організаційних заходів члени «Руської Ради» надіслали ноту звернення до імператора, в якій вказували на правонаступність з Головною Руською Радою 1848 р. [4, с. 9].

Характерно, що, незважаючи на асоціацію «Руської Ради», як органу русофілів, до іï складу на момент створення входили і народовці. Окремі дослідники, зокрема Л. Ілин, наводять аргументи, що народовці на чолі з Ю. Лаврівським (близько 25 осіб) намагалися сформувати в межах «Руської Ради» окремий клуб [4, с. 9]. Аргументом на користь такої думки дослідник визначає неспроможність обрання голови товариства у червні 1870 р. [4, с. 10]. Тільки 7 вересня 1870 р. русофіли зуміли зібрати більшість і провели перші установчі збори «Руської Ради», під час яких сімох народовців було виключено 3 товариства, а Ю. Лаврівський заявив про вихід 3 «Руської Ради». Так русофіли змогли отримати зверхність не тільки в українському національному русі Галичини, а й керівництво в першій політичній організації - «Руській Раді».

Створення «Руської Ради» в тогочасному галицькому суспільстві та місцевій періодиці асоціювалося зі створенням політичної партії. Так, русофільська газета «Слово» поділилася публікацією німецькомовної газети «Zukunft», у якій йшлося, що польська адміністрація Галичини занепокоєна створенням українцями першої політичної партії [9, с. 1]. Однозначно, що «Руська Рада» не була політичною партією класичного типу, адже не мала чіткої політичної програми. Це швидше був «політичний клуб за інтересами», приналежність до якого чітко ідентифікувала галичанина, як прихильник ідей русофільства.

Упродовж 70- pр. ХIX ст. «Руська Рада» забезпечила фактичне домінування русофілів в українському національному русі Галичини. Зосередивши свою увагу на нормотворчій діяльності в стінах сейму, русофіли у своїй ідеологічній риториці віддалилися від Росії та зосередили увагу на політичному протистоянні з поляками і одночасному декларуванні ліберального ставлення до імперської влади. На межі 1870-1880-х рр. відбувається налагодження співпраці між русофілами та народовцями, пошук спільних ідеологем та засобів до підвищення впливу «Руської Ради». Однак ані вступ молодих народовців у 1879 р. до «Руської Ради» [2, с. 242], ані інші заходи не допомогли вирішити політичну кризу, що сформувалася. Наявність політичного конфлікту з поляками не дозволяла двом українським політичним течіям витворити спільну програму дій.

Переломним моментом в еволюціï українського національного руху Галичини став судовий процес 1882 р. над О. Грабар [12, с. 317]. 3 одного боку, ці події продемонстрували те, що русофіли втрачають підтримку 
серед галичан, а поляки та австрійці готові оперативно протидіяти проросійським політичним крокам. При цьому народовці не відмовилися від ідеї подальшої співпраці 3 русофілами, і впродовж 1880-х рр. тривали активні перемовини стосовно консолідації українського суспільно-політичного руху Галичини. Однак авторитет русофілів був перешкодою на шляху цієї консолідації. Підтвердженням цього можуть слугувати результати виборів до Галицького сейму в 1883 р., коли українці змогли отримати тільки 9 мандатів, з яких 5 були представники народовців [2, с. 242; $14 ; 15]$. Це була найменша кількість мандатів, яку отримували українці за весь час існування сейму. Представництво у 9 осіб не дозволяло навіть самостійно формувати петиціï та звернення, оскільки для цього потрібно було 15 підписів. У таких умовах русофіли навіть заявили про відмову від сеймової діяльності.

За цих обставин успіх українського сеймового представництва у 1883-1889 рр., керівником якого був Ю. Романчук, був неможливим. Однак позитивним виявилося бажання народовців йти на компроміс 3 польськими депутатами. Як наслідок вдалося досягнути відкриття паралельних класів 3 українською мовою викладання у Перемишльській гімназіі, що стало свідченням спроможності народовці самостійно вести політичний провід українців. Це стало початком до активізації народовської течії, яка одночасно обрала для себе ненасильницький варіант внутрішньої боротьби з русофілами, що, на нашу думку, було виправдано з огляду на польську сеймову більшість.

Останні десятиліття ХX ст. стали часом посилення впливу народовців на національний провід. За словами М. Мудрого та О. Аркуші, для того часу була характерною зміна система австро-польсько-українських відносин, які в українському русі відображалися через трансформацію правових поглядів греко-католицької церкви, яка остаточно відмовилася від ідей русофільства та підтримала на парламентських виборах 1885 р. народовців [2, с. 243-244]. Останні остаточно відмовилися від співпраці з русофілами. Оскільки це було своєрідним гальмом для їх внутрішньої еволюції [2, с. 245]. Однак на практиці створити дві окремі політичні організації, які б змогли самостійно i успішно провести вибори було, неможливо, хоча в 1885 р. народовці заснували «Народну раду». Власне Галицький сейм був чинником, який сприяв консолідації русофілів та народовців. Так відбулося під час виборів 1889 р., хоча ідеологічно народовці все ж мали більший вплив. Свідченням цього є те, що керівником української сеймової фракції став лідер народовців Ю. Романчук, а заступником - русофіл М. Антонович [1, с. 75].

Саме початок роботи нової сеймової каденції 1890 р. можна вважати початком нового етапу в процесі структуризації національно-політичних сил українців Галичини. Політика «нової ери», яку активно підтримували народовці, і зокрема Ю. Романчук, призвела до остаточного розмежування з русофілами. Подальші факти співпраці мали місце тільки під час сеймових виборів чи роботи сейму, що було спробою протистояти чимраз зростаючій полонізації.

На початку 1870-х рр. паралельно 3 русофільською та народовською суспільно-політичними течіями починає розвиватися нова - радикальна. Останні, орієнтуючись на соціальну складову, у своїх політичних програмах відмовлялися від компромісних та половинчастих рішень. Основним ідеологом радикалів виступав $M$. Драгоманова, погляди якого активно поширювалися на сторінках газети «Друг» [11, с. 203]. В одному з листів М. Драгоманова в редакцію згаданої газети говорилося: «На мою думку, краще не сперечатися, а зайнятися спільною роботою в безспірному 


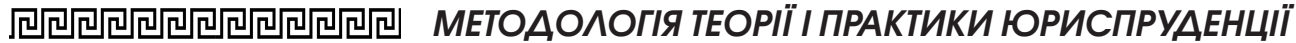

напрямі: просвітою народу, його мовою, зближенням вищих верств з народом, між іншим і при помочі літератури про народ i народною мовою» [3, с. 399]. Вплив ідей М. Драгоманова на галичан важко переоцінити. Їх безпосереднім наслідком був розкол в середовищу української інтелігенції, молодше покоління якої радикалізувалось і відмежувалося не лише від русофілів, як того закликав M. Драгоманов, а й від народовців, яким бракувало рішучості у досягненні власних політичних планів. Вплив ідей $M$. Драгоманова влучно охарактеризував I. Франко, який і сам під цим впливом зацікавився політичної діяльністю і був одним із творців радикальної течії. Він писав: «Статті й листи Драгоманова - то були мов удари батога» [13, с. 350]. Ми також погоджуємося 3 тим, що ідеї М. Драгоманова, які йому не вдалося реалізувати в Наддніпрянщині, знайшли сприятливий «грунт» у Галичині. Показово, що австрійська влада оперативно відреагувала на галицьких радикалів, наслідком чого стали численні арешти студентської молоді. За згадку в листуванні $M$. Драгоманова i M. Котурницького про I. Франка останнього було арештовано і інкриміновано участь в таємних організаціях та «розповсюдження соціалістичних ідей» [11, с. 205].

Слід відзначити і той факт, що радикальна течія Галичини дуже швидко еволюціонувала. Після створення 1890 р. Русько-Української Радикальної Партії І. Франко та $M$. Павлик, які були їі організаторами, вже не вважалися представниками радикального руху. Із переписки М. Павлика та Д. Рагоманова відомо, що вони навіть намагалися применшити революційний запал молодшого покоління радикалів. Він писав, що їм вдалося добитися, щоб молоді «трохи попустили 3 глупого марксизму» [11, с. 205]. Це було наслідком того, що до створення цієї партії спричинилися і народовці, які зазнали вну- трішнього розколу та еволюціі. Засновники народовської течії обрали для своєї діяльності помірковані підходи, натомість молодше покоління радикалізувалося під впливом ідей $M$. Драгоманова і формувало нову радикальну течію.

3 іншого боку, вплив радикалів на широкі верстви суспільства був не значним. Свідченням цього може стати відсутність послів у Галицькому сеймі, хоча, з іншого боку, самі радикали були противниками методів мирної законотворчості, що могла вплинути на політичну ситуацію в краї зокрема та імперії загалом. На нашу думку, основним здобутком галицьких радикалів було формування власних політичних сил та витворення концепції соборності українських земель. Окрім того, позиція радикалів показала народовцям на необхідності остаточного розриву 3 русофілами, які на початку XX ст. почали відкрито агітувати за колаборацію з Російською імперією.

Остаточна трансформація суспільно-політичних течій галицьких українців відбулася в перші десятиліття XX ст. і стала для галицьких русофілів часом занепаду. Молоде покоління відмовлялося від ідеї національної єдності з Росією, вказуючи на мовні та культурні зв'язки. Так, виступаючи у сеймі 1908 р., М. Король заявив, що «почуває себе малорусином, а не росіянином» [2, с. 253]. Така позиція була закономірною і виправданою для усіх політиків, які й надалі мали бажання брати участь у громадсько-політичному житті. Уряд Австро-Угорщини почав всіляко перешкоджати поширенню проросійської пропаганди, а тому галицькі русофіли стали об'єктом посиленої уваги з боку силових структур. Тому молоде покоління змінювало свої погляди і переорієнтовувалося на відстоювання ідеї єдності з Наддніпрянщиною.

У 1907 р. русофіли остаточно себе скомпрометували. Один із галицьких послів імперського парламенту, що 


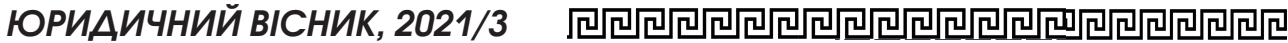

дотримувався русофільських поглядів, виступив російською мовою. Це викликало обурення як із боку народовців, так і решти депутатів і офіційної влади, оскільки російська не належала до крайових мов у Австріі. Після цього русофіли вийшли з української парламентської фракції «Український клуб» та остаточно відірвалися від української національно-визвольної боротьби [7, с. 12].

Висновки. Таким чином, створення та діяльність Галицького сейму мали вагомий вплив на український суспільно-політичний рух. По-перше, відбулася його чітка структуризація і виокремлення ідеологічних засад русофільства та народовства. По-друге, протистояння з польською сеймовою більшістю в стінах сейму змушувало українців, незважаючи на ідеологічні відмінності, проводити спільну політику. Такий компроміс спостерігався до початку 1890-х рр., коли русофіли не скомпрометували себе остаточно співпрацею з імперією Романових. Натомість народовці на чолі з Ю. Романчуком і декларуванням угодовських тенденцій з поляками та австрійцями змогли очолити національний провід. Одночасно саме під впливом сеймової діяльності відбувся процес політизації національного руху, а перша партія була заснована представниками нової радикальної течії та народовцями у 1890 р.

У статті визначаеться ступінь впливу Галицького крайового сейму на проиес еволюиії основних ідеологем представників русофільської та народовської течій, а також встановлюються засадничі принйипи організації радикального руху, його партійного оформлення. Характерно, шо на момент свого створення та ідеологічного оформлення ані русофіли, ані народовиі у 1860-1880-х рр. не були готові до самостійної політичної діяльності. Перші розуміли ініціативи поляків із підтримки народовиів, такі як бажання «розсварити русинів», а другі в порозумінні бачили можливість легально $і$ з правової точки зору відстояти власні національно-культурні інтереси. Створення ma діяльність Галицького сейму мали вагомий вплив на український суспільно-політичний рух. По-перше, відбулася його чітка структуризація $i$ виокремлення ідеологічних засад русофільства та народовства. По-друге, протистояння з польською сеймовою більшістю в стінах сейму змушувало україниів, незважаючи на ідеологічні відмінності, проводити спільну політику. Такий компроміс спостерігався до початку 1890-х рр., коли русофіли не скомпрометували себе остаточно співпрацею з імперією Романових. Натомість народовиі на чолі $3 Ю$. Романчуком $i$ декларуванням угодовських тенденцій із поляками та австрійиями змогли очолити національний провід. Одночасно саме під впливом сеймової діяльності відбувся процес політизаияї національного руху, а перша партія була заснована представниками нової радикальної течії та народовиями у 1890 р. Загравання русофілів із ідеями панславізму призвели до того, що Російська імперія звернула на них увагу $i$ надавала їм певну допомогу. Для підтримки русофілів імперія Романових вдавалася $i$ до різного роду зловживань, $i$ просування в політичний простір Австріі вигідних їй політиків. Польський політикум Галичини почав підтримувати народовиів як єдину силу, що могла сформувати альтернативу русофілам. Підтримка поляками народовиів була закономірною з огляду на бажання перших налагодити політичний компроміс.

Ключові слова: Галичина, суспільно-політичний рух, галицький сейм, сеймова діяльність, народовці, русофіли, радикали. 
Krykhovetskyi I. THE INFLUENCE OF SEY ACTIVITY ON THE EVOLUTION OF UKRAINIAN SOCIO-POLITICAL CURRENCIES OF THE SECOND HALF OF THE XIX - EARLY XX CENTURY

The article determines the degree of influence of the Galician Regional Sejm on the process of evolution of the main ideologues of the Russophile and popular currents, as well as establishes the basic principles of organization of the radical movement, its party design. It is noteworthy that at the time of its creation and ideological design, neither Russophiles nor populists in the 1860s and 1880s were ready for independent political activity. The former understood the initiatives of the Poles to support the populists as a desire to "quarrel with the Ruthenians» and the latter saw in the agreement an opportunity to legally and legally defend their own national and cultural interests. The creation and activity of the Galician Sejm had a significant impact on the Ukrainian socio-political movement. First, there was a clear structuring and separation of ideological foundations of Russophilia and populism. Secondly, the confrontation with the Polish Sejm majority within the walls of the Sejm forced Ukrainians to pursue a common policy, despite ideological differences. Such a compromise was observed until the early 1890s, when the Russophiles did not completely compromise themselves by cooperating with the Romanov Empire. Instead, the Narodniks, led by Yu. Romanchuk, were able to lead the national leadership by declaring agreement tendencies with the Poles and Austrians. At the same time, it was under the influence of the Sejm that the process of politicization of the national movement took place, and the first party was founded by representatives of the new radical current and the populists in 1890. The flirtation of Russophiles with the ideas of Panslavism led to the fact that the Russian Empire paid attention to them and provided them with some assistance. To support the Russophiles, the Romanov empire resorted to various abuses and promotions in the political space of Austria, politicians who benefited from it. Polish politicians in Galicia began to support the Narodniks as the only force that could form an alternative to the Russophiles. Polish support for the Narodniks was natural given the desire of the former to reach a political compromise.

Key words: Galicia, sociopolitical movement, Galician Sejm, Sejm activity, populists, Russophiles, radicals.

\section{Література}

1. Аркуша О. Галицький сейм: виборчі кампанії 1889 і 1895 рр. Львів : [б.в.], 1996. 173 c.

2. Аркуша О., Мудрий М. Русофільство в Галичині в середині XIX на початку XX cm.: генеза, етапи розвитку, світогляд. Вісник Львівського університету. Серія історична. Bun. 34 / Bidn. ред. М. Крикун. Львів, 1999. С. 231-268.

3. Драгоманов М.П. Чудацькі думки про украӥнську національну справу. Вибране. Киї, 1991. С. 461-558.

4. Ілин Л.М. Правові та організаціиині засади діяльності української сеймової фракції «Руський клуб». Приватне та публічне право. 2017. № 3. С. 8-11.

5. Лавринюк В. Революція 1848 року, ii результати та значення. Наукові записки тернопільського державного педагогічного університету імені Володимира Гнатюка. Bun. VII. Серія: Iсторія: Збірник наук. пращь. / За заг. ред. проф. М.м. Алексієвия. Тернопіль, 1998. C. $27-35$.

6. Левицький K. Історія політичної думки галицьких українців: 1848-1918: В 2 ч. Львів, 1926-1927. Ч. 1. 736 с.

7. Михальський Ю.В., Сова А.О. Москвофіли та український національний рух у Галичині в кінці XIX на початку XX століття: погляд крізь призму сучасності. Вісник Львівської комериійної академії. Серія - гуманітарні науки. Львів, 2010. Bun. 9. С. 10-14. 
8. Наши дила. Руская Рада. Слово. 1870. 22 априля (4 мая), Ч. 31. С. 1.

9. Партіи на Галицкой Руси. Слово. 1870. 3 (15) іюня, Ч. 43. С. 1.

10. Подолинський В. Слово перестороги. Львів. URL : http: //litopys.org.ua/ perestor/sloworus.htm.

11. Салтовський O.I. Концепції української державності в історії вітчизняної політичної думки (від витоків до початку ХХ сторіччя). Київ : Вид. ПАРАПАН, 2002. $396 \mathrm{c}$.

12. Слотюк Т. Публіцистичний дискурс москвофільства як суспільного явища в контексті української історії та преси. Вісник Львівського університету. Серія : Журналістика. 2014. Bun. 39(1). C. 317-329.

13. Франко I. Украӥна Молода. Вибір із творів. Нью-Йорк, 1956. С. 338-389.

14. Чорновол I. Забутий учитель I. Франка. Микола Антонович - професор і посол на Сейм. Перемишль і черемиська земля протягом віків. Збірник наукових праць та матеріалів Міжнародноі наукової конференції. Перемишль-Львів, 2001. С. 185-192.

15. Чорновол I. Українська фракиія Галищького крайового сейму 1861-1901 рр. Львів, 2000. 270 c. 